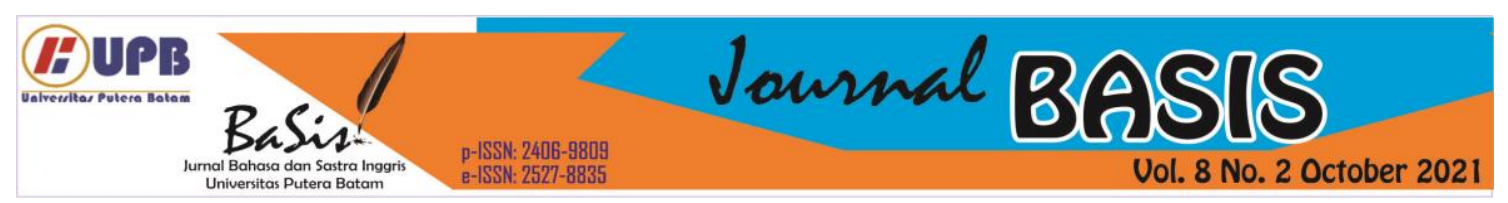

\title{
IMPLEMENTATION OF ONLINE CREATIVE PEDAGOGICAL MODELS IN EXTENSIVE READING SUBJECT
}

\author{
Elisa Nurul Laili ${ }^{1}$ \\ Universitas Hasyim Asy'ari, Jombang, Indonesia \\ elisa_nurullaili@yahoo.co.id \\ Sakhi Herwiana ${ }^{2}$ \\ Universitas Hasyim Asy'ari, Jombang, Indonesia \\ sakhyna@gmail.com
}

\begin{abstract}
Covid-19 significantly influences teaching and learning activities. Lecturers need to be more creative to optimize the available electronic tools for supporting the teaching and learning process. Many problems faced by both lecturers and students, especially in private university whose its students are from economically low society, when they are disrupted by this condition. Creative teaching and learning process is needed to make the class more effective and attractive. Besides, it also shapes the students' minds to follow every sophisticated change and condition in the future by seeking the exact and creative problem-solving. This research aims to describe the implementation of the online creative pedagogical learning models in English Education Department students on Extensive Reading course. The research uses a descriptive qualitative method, which is designed as classroom action research. This research conducted in English Education Department of Hasyim Asy'ari University Tebuireng Jombang, with 25 participants. The result of this research shows that online creative pedagogical models can be used for solving students' problems, such as Google Classroom, Youtube, and Instagram TV for a synchronous meeting, and Google Meet for an asynchronous meeting. The result shows that those media suitable for implementing creative onli also become alternatives for students who have limited access to the internet because they live in remote areas or have low budgets, but those media are practical and effective.
\end{abstract}

Keywords: creative pedagogy, distance learning, extensive reading, online learning

\section{INTRODUCTION}

Education plays an important role in the process of improving the quality of the source of human power. Realizing the importance of quality human resources, then the government together have been and continue to strive realizing this mandate through various more education development efforts quality, among others through development and improving the curriculum and evaluation system, improvement of educational facilities, development and procurement of teaching materials, as well as training for teachers and other education personnel. 
In line with the era of globalization, science developing knowledge and technology very fast and increasingly sophisticated, with the wider role the teacher is needed which has character. A nation which the community is not ready almost will certainly fall by the enormity of its natural change and the rapid advancement of scientific knowledge and technology as characteristic globalization itself. Therefore, the quality of education must be increased. School as an educational institution must have creative thinking skills, critical thinking, problemsolving, communication, collaboration, or what is commonly called $4 \mathrm{C}$ (Erdoğan, 2019; Almarzooq et al., 2020; Widodo \& Wardani, 2020).

This demands the role of the educator to develop good hard skill skills and soft skills for students in learning at school to get into the world of work and compete with other countries. The teacher prepares everything such as curriculum, plan Implementation of learning, and models or methods integrated with 21 st-century learning. By developing 21st-century skills in learning, it is expected for every individual to have the skills supported by various opportunities and challenges that will face in the era of advances in technology and information. Some experts explain the importance of mastery on various skills of the 21 st century as one of means to gain success in the century in which the world developing rapidly and dynamically.

Learning English functionally and communicatively emphasizes more students learning languages with language as a tool for communication. Students are not just learning about language knowledge but are learning to use language for communication purposes. Learning English with the communicative approach is directed to form communicative competence, namely the competency of the ability to use English as a communication tool, both in the aspects of understanding, aspects of use, and aspects of appreciation (Suparno, 2001). The foregoing means, through learning English it is expected that students have the ability to capture the meaning of a message or information delivered and have the ability to reason and restate the message or information received. Students are also expected to have the ability to express various thoughts, ideas, opinions, and feelings using good language. Communicative competence can be achieved through the process of skills that are trained and experienced in learning activities.

Reading is one learning skill to sharpen up the understanding of written messages. Students improve their thinking ability through some information critically. Through reading activities, students can understand and follow the development of science. Reading ability is an important skill for students to compete and keep up with the development era. To support and improve deep reading skills learning, the teacher has to design certain appropriate learning models with the characteristics and needs of students. A teacher must also pay attention to the learning material to increase students' reading interest.

For students of the English Education Study Program, reading course is still considered difficult. It can be seen when they are given a text, and many students have not been able to answer questions about the text well. They still influenced by hoaxes on media and many obstacles related to critical thinking. It means that their critical reading ability is still relatively low. If they were told to revisit what 
they read using their own words, the story's main idea was still not right on target. This research investigates the implementation of an online creative pedagogical learning model in the Extensive Reading course.

\section{LITERATURE REVIEW}

Creativity is wealth personal or personal properties which are realized in attitude or character such as flexible, open, autonomous, generous, desire, curiosity, firm or strong-minded. It is also including the ability to describe ideas, the ability to judge yourself realistically, and all of which are necessary (prerequisite) to bring up creativity. Development of creativity in the classroom (teaching and learning process) will produce creative students and participants who generally have more abilities, and tough character compared to ordinary students. Ability to think creatively as a creative component will be resulted in effective learning. Furthermore, developing high reasoning power can be used to solve problems in teaching and learning activities. Creative learners potentially will produce superior learning. In other words, students who have the ability to think creatively will have high intrinsic motivation in learning. They also have strong, confident drive and high thinking skills (Pentury, 2017: 266; Misdi, 2018).

According to (Wijaya, Cece dan Rusyan, 1991: 189), one of problems faced in the education world is fostering creativity teacher. Teacher creativity in the teaching and learning process has an important role to motivate student learning. Creativity is defined as ability to create a new product, either both totally new or which has such modification or change by developing things that are already exist. When it is associated with teacher creativity, the teacher may be concerned to produce some strategies, completely new and original, or it could be a modification of various strategies which has been existed, so it generates new forms.

Teaching is no longer conveying business aims, but rather efforts to create environmental system to teach students optimally. Teaching for this context, requires a strategy appropriate to that goal. In order to achieve that goal, it is necessary to foster and develop the creativity of teachers in managing teaching programs with strategies teaching and learning in accordance with a variety of modifications (Pentury, 2017: 267).

The creative teacher is a person who masters or experts on science he/she teaches, and they have autonomy in class (teaching and learning process). The creative teachers set goals and objectives, build basic skills, encourage the achievement of certain knowledge, stimulate curiosity and exploration, build motivation, encourage trust self and dare to take risks, focus on mastery of science and competition, support positive outlook, provide balance and the opportunity to choose and find, develop self-management, ability or metacognitive skills, organize learning with using a variety of techniques and strategies to facilitate the birth of the creative display (embodiment), build environment which is conducive to the growth of creativity, and encourage imagination and fantasy. In conclusion, creative teachers will provide creative inspiration to students (Fisher, 2004).

Productive creative learning has some of the characteristics that set it apart with other learning. According to Suryosubroto, (1996: 124), characteristic of productive creative learning, are: a) Student involvement in intellectual and emotional learning. This involvement is facilitated through 
giving opportunities for students to do exploration of the concept of a scientific field is being reviewed and interpreting the results the exploration. Students are given freedom to explore various sources relevant to the topic, concept, or problem being studied by them. This exploration will increase student interaction with the environment and his own experience, as a medium to construct knowledge, b) Students encouraged to find or construct a concept themselves that is being examined through interpretation done with various ways such as observation, discussion or experiment.

The characteristics of the model productive creative learning helps the teacher applies this model inside learning so that students can develop creative thinking skills, responsibility and cooperation within solve a problem in learning. Creative learning context, can be grown by creating an atmosphere class that allows students and teachers feel free to study and explore important curriculum topics. Teacher asks questions that make students think hard, then pursue an opinion or idea about many perspectives. The teacher also encourages students to demonstrate understanding of important topics in the curriculum in its own way (Black in Suryosubroto, 1996: 126).

\section{RESEARCH METHOD}

The approach used in this study is a qualitative approach. In line with focusing and its natural background in the form of activities in the classroom, the action research design applied is classroom action research. This qualitative approach is based on the idea that this study seeks to reveal various symptoms that provide meaning and information according to the context and purpose of the research through data collection. The data collection is carried out in a natural setting, with the researchers as the main instrument in data collection.

The data were collected during the pandemic Covid-19 classes, on 2 September - 15 December 2020. It was taken by 12 meetings. The sampling or population used to be investigated were 25 students of the 7th semester of the English Education Department of Hasyim Asy'ari University, academic year 2020/2021. Then, all of them become the respondents of this research. This research is conducted in Extensive Reading subject class, which are fully online in the odd semester. Before conducting the research, the researchers also do pre-observational research to know and choose the best media for teaching and learning online. After that, the data were collected by observing and taking notes on the respondents, to answer the research questions. After data were collected, the researchers then classify, reduce and categorize it based on the research questions. After the categorization, the researchers then began to analyze every data. The analysis were done systematically and descriptively.

\section{RESULT AND DISCUSSION}

The findings or results of this study are explained in the subheadings below. It is divided into 5 parts: Preactivities, Conveying Materials, Giving Assignment, Giving Feedback, Evaluating and Scoring. Every parts are explained on every subheading. The researchers also add some discussion related to the topic on implementation of online creative pedagogical learning model in Extensive Reading course. 


\section{Pre-activities}

Coordinating and Synchronizing the Media Used for Teaching and Learning for Extensive Reading Course

The Covid-19 pandemic have disrupted teaching and learning processes for almost one academic year, odd and even semester of 2020/2021 academic year. Most of universities, including Hasyim Asy'ari University announced that every classes or courses must be held online. So, for English Department students, we also studied in distance. We usually called distance learning for online teaching and learning activities. Here, one of the researchers, also, as the lecturer for Extensive Reading course. So, the research had been done in odd semester of 2020/2021 academic year.

The lecturer tries to think creatively, what kind of media which is suitable to be used for teaching at Extensive Reading class. The lecturer must consider many aspects in order the teaching and learning activities still be conducted and could be accessed by all of students. The lecturer and students then discussed thorugh Whatsapp Group for choosing best media to be used this semester.

Based on the discussions, the lecturer can see the answer and reasons of students. Some of the students live at rural or remote areas, so they cannot reach the signal smoothly. They must go to other places, in order to access the courses or classes. Based on the reason above, the lecturer cannot use synchronous media e.g. Zoom, Google Meet, Skype, Microsoft Team, etc. on every meeting. So, the lecturer decided to choose Google Classroom, which is categorized as asynchronous media. Google Classroom is also chosen because of its compatibility for many kind devices, such as PC, laptop, or handphone (android or iphone).

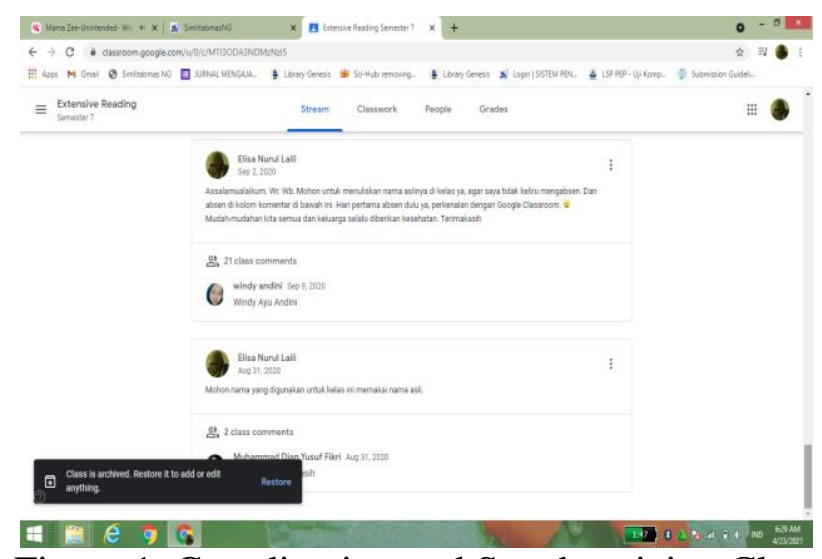

Figure 1. Coordinating and Synchronizing Class

Google Classroom is also chosen because it is supported by the quota subsidy assistance provided by Ministry of Education. So, it will not spend other quota owned by lecturer and students. This subsidy is given to help students and lecturers accessing the internet sources for teaching and learning. It also given during the pandemic to support the economic difficulties for Indonesian educational actors, such as teachers, lecturers and students.

Beside that, Google Classroom is also chosen to be used than SPADA Kemdikbud and Moodle or other asynchronous media because it is easier to use. The features are catchy, simple and complete for both lecturer and 
students. And it also do not spend a lot of internal memory to use in devices. In other cases, the accessibility is more affordable, because it is provided by Google.

\section{Conveying Materials}

When conveying materials, lecturer used two media. Google Classroom and Google Meet. The asynchronous media used are Google Classroom and Youtube. While the synchronous media used for conveying material is Google Meet.

\section{Google Classroom}

The creativity used by the teacher in Google Classroom is selecting the materials in accordance with the lesson plan or syllabus. Because the Extensive Reading class is not only to read, but also supported by other materials, so the lecturer need to combine the materials related to the importance of extensive reading, benefit and tips for doing extensive reading. Beside the materials taken from official channels on Youtube, the students were also asked to join webinar on empowering Reading that was held on Zoom, and made resume or report on their webinar activities.

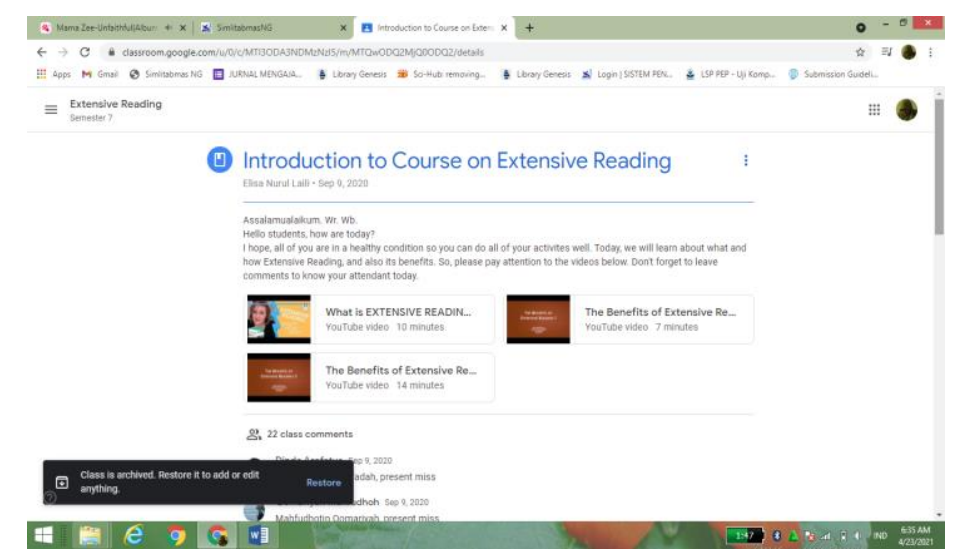

Figure 2. Conveying Material via Google Classroom

In the last material conveying, the lecturer give the Critical Discourse Analysis (CDA) material to be one of analysis framework for doing extensive reading. In this case, students not only know how to read as passive skills, but also hoped to produce the result of their reading in order to become active skills, writing report or analysis of texts they have been read. It is hoped, the students can make some analysis using suitable framework, such as CDA after finishing the project. 


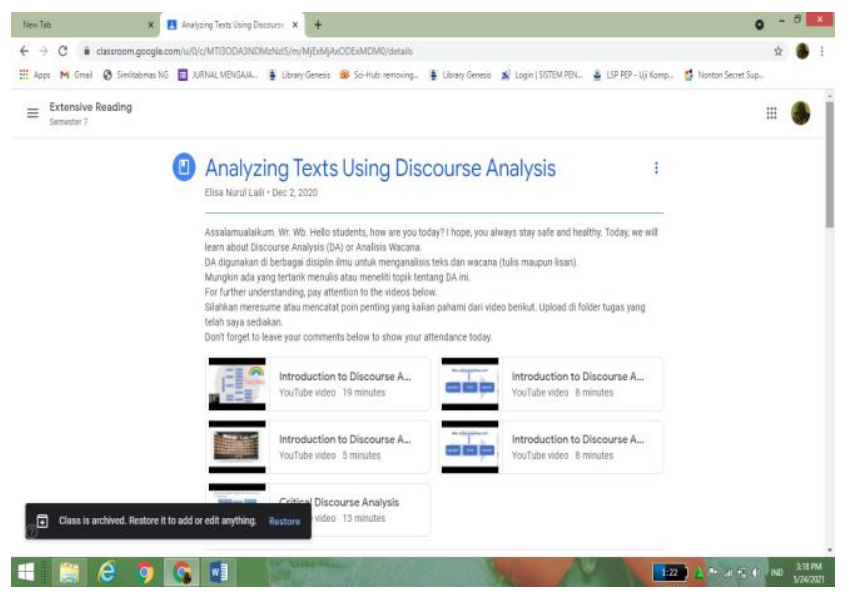

Figure 3. Material of Discourse Analysis as Framework for Analysing Text

\section{Google Meet}

Google Meet is also used as media for synchronous learning. But, the frequency is only twice for maximum meeting. It because of students' lackness or limitation of signal in their area. So, the meeting used Google Meet is on seventh meeting (before mid term test) and fifteen meeting (before final test).

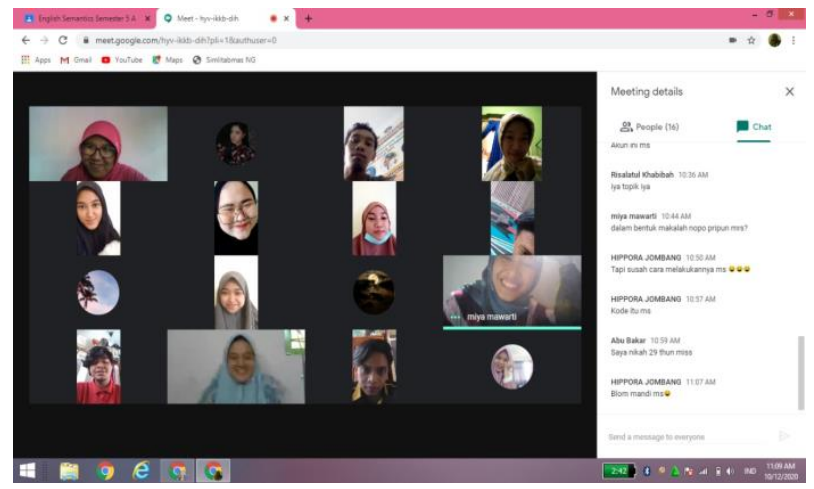

Figure 4. Conveying Material via Google Meet

The activities used Google Meet including reviewing material, questioning and answering, and discussing. Reviewing material are related to materials and duties given before mid term test and final test. Questioning given by lecturer to test the students' undertanding related to some materials given via Google Classroom. While answering is responses given by the lecturer to the questions asked by the students for materials or other topic. Finally, discussing activities related to peer students' discussion.

\section{Giving Assignment}

The lecturer also made some assignments for students. Beside project-based assignment, the students also given other duties to be completed for fulfilling Extensive Reading course. The lecturer give four kinds of assignments to complete. Here are the explanation of each.

\section{Assignment 1}

For the first assignment, the students were asked to resume materials from Google Classroom. It is related to the definition, scope, benefits, tips and tricks for doing extensive reading. Resume assignment is also given when 
the students were asked to join the webinar, in order to know how deep their understanding about webinar's materials.

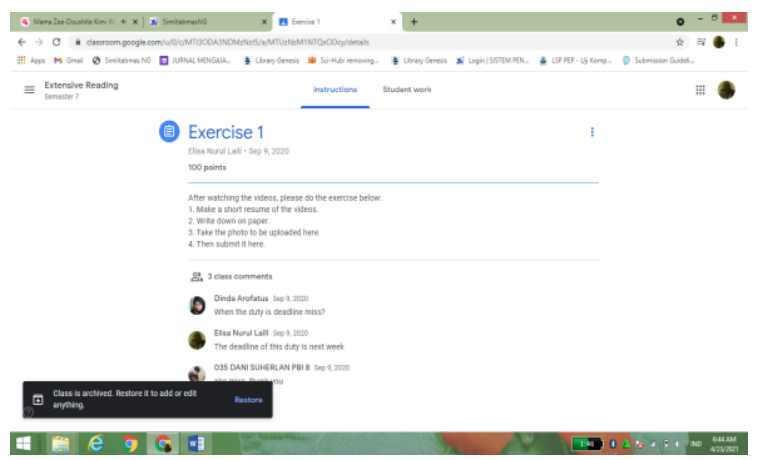

Figure 5. Resuming Materials

After resuming the materials, students were asked to submit their works on the folders available, created by the lecturer to be checked later.

\section{Assignment 2}

The second assignment, the students were asked to choose one book to be read during one semester. This book had to be read and reviewed by the students individually.

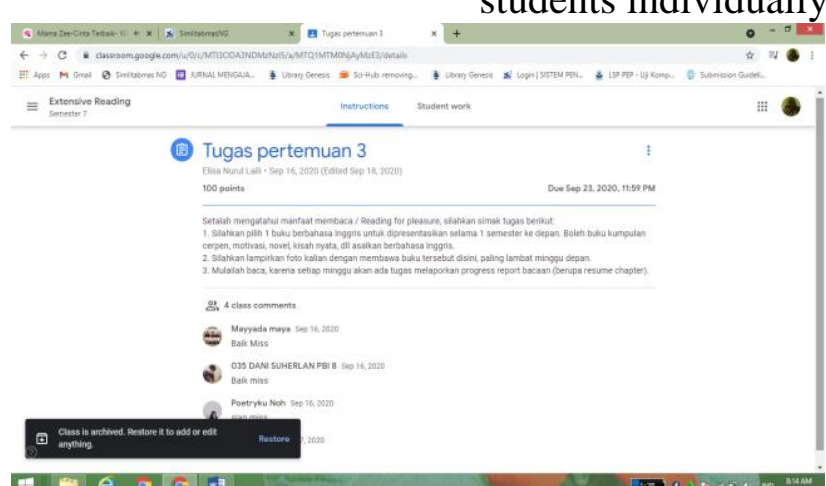

Figure 6. Choosing Book to be Read during One Semester Learning

They had to report every progress they made on every meeting by making the short written review. Then, they take the photograph to be uploaded on available folder in Google Classroom provided by the lecturer. Here is one example of submission folder for progress report of students reading assignment.

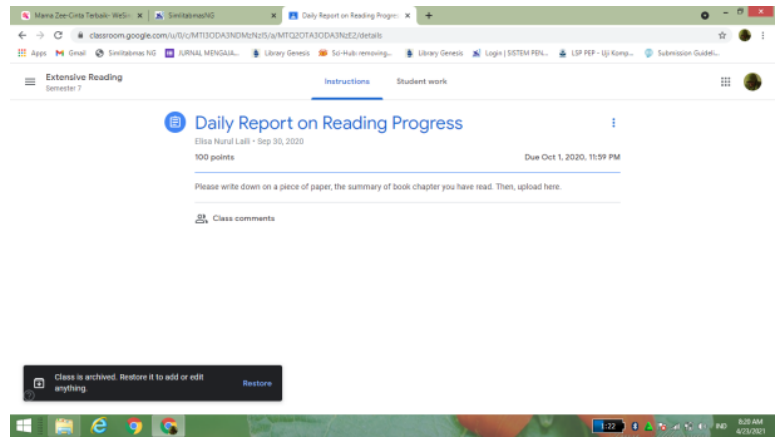

Figure 7. Submission Folder 


\section{Assignment 3}

The third assignment, students were asked to make short review in the form of video. Then, they had to uploaded on YouTube or instagram. This activity made students used creative thinking. Some of them used many kinds of video maker tools. For examples, Zoom presentation recorder, Pow Toon,
Cyberlink Youcam, Prezi Video, and others. It prove their creativity on creating video to be interested to be watched by all the viewers. Below is one of videos taken from students' link on

Youtube:

https://www.youtube.com/watch?v=HF vaw_k8Sfs.

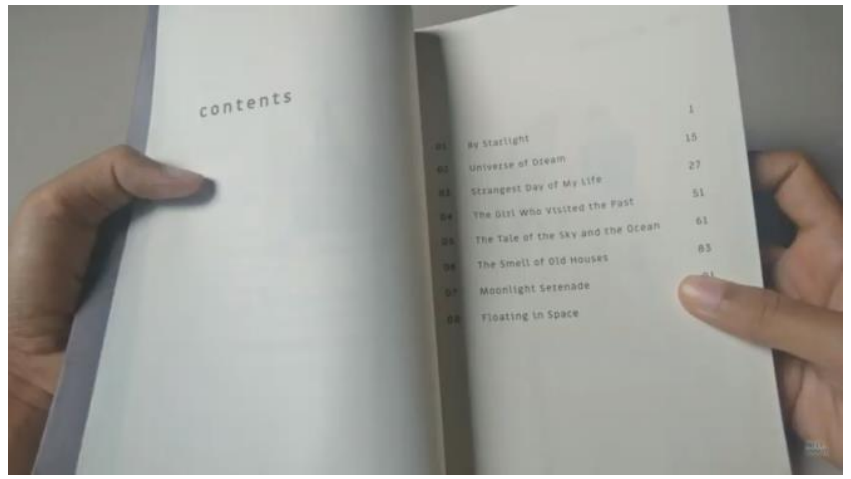

Figure 8. Making Book Review and Uploading it to YouTube

Beside YouTube, students were also permitted to submit their video project on Instagram. They used Instagram TV because the duration is longer than usual post. Here is the example of student's videos taken from Instagram $T V$ link as follows: https://www.instagram.com/tv/CGq4je0 gg4K/?igshid=1vkk1pkuq7vno.

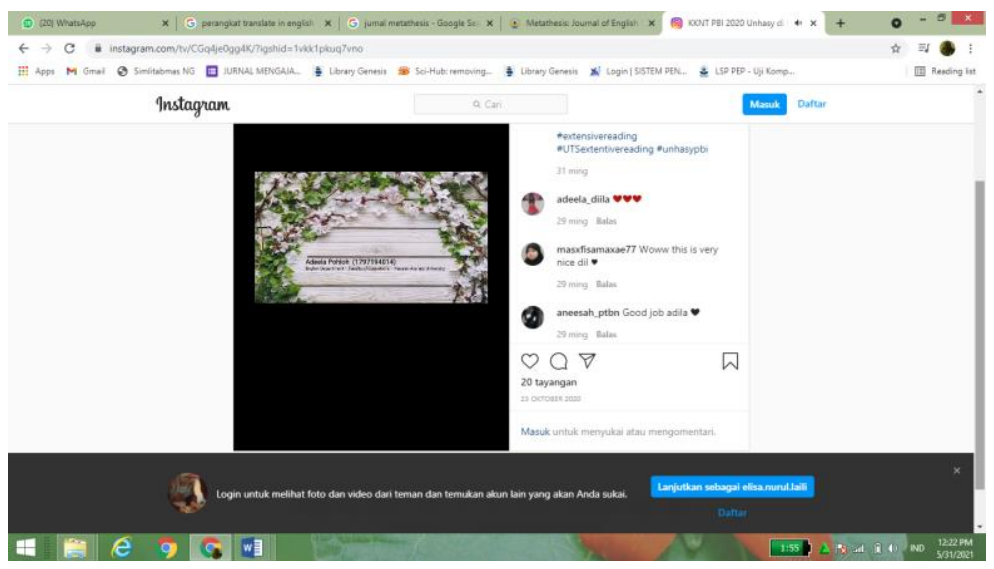

Figure 9. Making Book Review and Uploading it to Instagram TV

Beside creativity on the process of making short video of book review, they also shows other skills, such as public speaking, story telling, or acting as what they had arranged on their concept of video. All of them in line with the principles of creativity of thinking.

\section{Assignment 4}

For the fourth assignment, the students were asked to give comments, responses 
and criticism to other works. It means, every students had to join friends' videos to watch, then gave comments or criticism to their friends work. It was hoped to motivate and appreciate other people work.

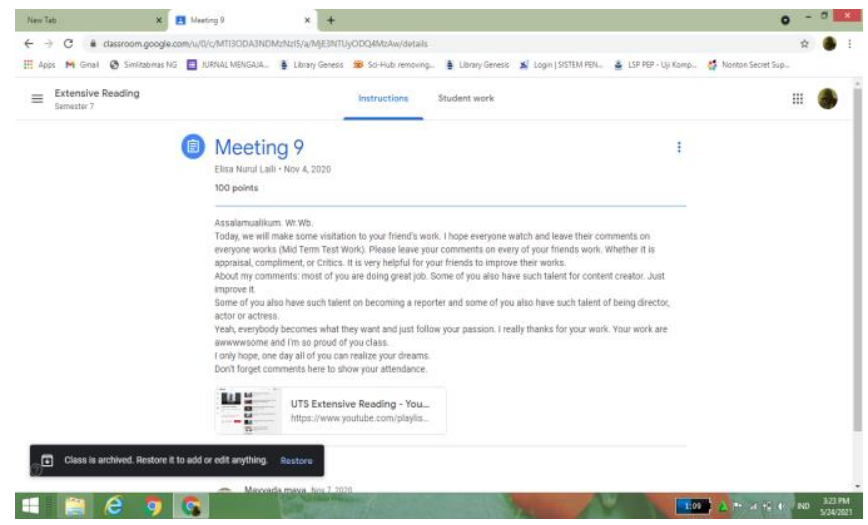

Figure 10. Giving Comments, Responses and Criticisms to Other Works

After they have finished the somments or criticisim, they had to take screenshoot as the evidence to be submitted to the available folder provided by the lecturer.

\section{Assignment 5}

For the fifth assignment, the students are graded for all portofolio of the assigments that had been done during one semester. This assignments involving all resuming activities and participation in the class. The total of resuming activities are five resumes. While the participation consists of $75 \%$ total of the attendance for 16 meetings (including mid term test and final test) and participation on submitting the weekly progress report on reading book chosen by them.

\section{Giving Feedback}

The feedback were given to every students on the submitted assignments. The lecturer check one by one of their work sheets on Google Classroom folders. He lecturer also give comments, suggestions or correction to students works, if any. Here is the figure of feedback column.

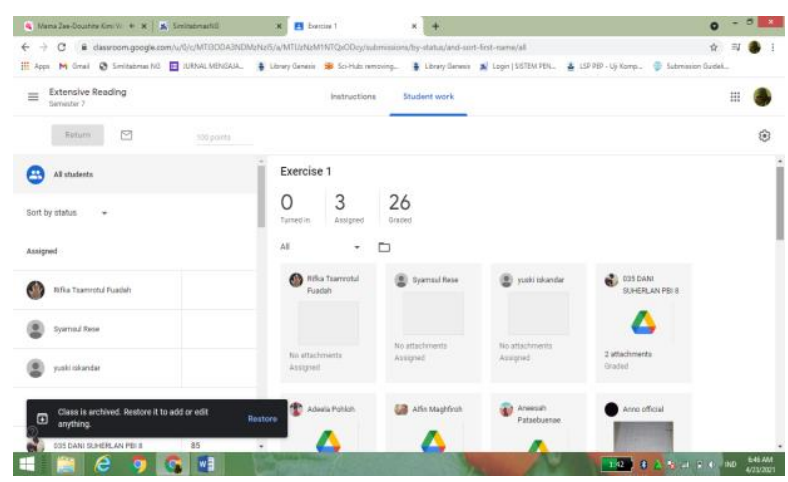

Figure 11. Lecturer's Feedback

The lecturer also gave special attention to the students who do not submit the assignment or late submission. The lecturer send text to remind about the late or missed submission by Whattsapp or giving 
comment privately on his Google Classroom account to keep and maintain their privacy. Sometimes, the lecturer here also give motivation to students, because this pandemic situation could bring them into bored and stagnant or monotonous teaching and learning activities. So that, whatever their condition, the lecturer can understand their problems and give more opportunities for them to fulfill their duties.

\section{Evaluating and Scoring}

Rubric is a guide for learning facilitators (teachers or lecturers) to conduct consistent and credible assessments that can be accounted for student works' quality. Scoring rubrics defined as a detailed description of the type specific performance and criteria to be used to assess (Arends, 2008: 244). Rubric can be interpreted as a guideline for performance appraisal or the results of student work consisting of the score and criteria that must be met to achieve that score. Rubric is also one of the alternative assessments that can used to measure and assess students comprehensively. It says comprehensive because of student competence not only seen at the end of the process only, but also during the process take place. Therefore, the rubric can be doubles as a guide work and as an evaluation instrument (Mahmud, 2013).

In general, there are two types of rubrics, namely the holistic rubric and the analytic rubric. Holistic rubric, which is a rubric that assesses the process as a whole without there is a division of components separate; analytic rubric, i.e. rubric which assesses the process separately and the end result is with combine the ratings of each component (Nitko, 1996). Here, the lecturer evaluated and gave score to the students on every of their assignments used both holistic and analytic rubrics. Analytic rubric used to assess each individual criteria separately, then combine the assessments of each criterion to provide an assessment to the overall quality of students' performance. While holistic rubric used to provide an assessment of overall or holistic to the quality of students' performance.

There were four criteria to pass this course: participation, assignments, mid term test, and final test. Participation and mid-term test took $20 \%$ of total score grading, while assignments and final test took $30 \%$ of total score grading. The criteria for participation and assignments were attending the class, proven by giving comments on Google Classroom and submitting the assignments on available folders provided by the lecturer. The mid-term test and final test were project-based reports which were also submitted in the folders provided by the lecturer in Google Classroom. For mid-term test, the project was oral presentation, by submitting video of short review the book they had read during one semester. While for final test, the project was all written review of the book they had read during one semester.

The criteria for grading the assignments can be seen formulated in the rubrics below.

\section{Assessment Rubric for Resuming Activities}

For the first assignment, the students were resuming materials from Google Classroom. The assignments is individual project, so the grade is for each student individually. The materials selected by the lecturer in accordance with the topic, and taken from the Youtube official channels. Here, the lecturer used the rubric below: 
Table 1 Assessment Rubric for Resuming Activities

\begin{tabular}{lll}
\hline \multicolumn{1}{c}{ Grade } & Score & \multicolumn{1}{c}{ Indicator of activities } \\
\hline Fail & $\leq 40$ & $\begin{array}{l}\text { The resume is written irregularly and do not contain } \\
\text { problem solving } \\
\text { The resume is written irregularly but containing lack } \\
\text { of problem solving } \\
\text { The resume is written systematically, but containing } \\
\text { Good }\end{array} 41-60$ of problem solving \\
Very good & $81-90$ & $\begin{array}{l}\text { The resume is written systematically, containing } \\
\text { problem solving, but not innovative } \\
\text { The resume is written systematically, containing } \\
\text { problem solving, and innovative }\end{array}$ \\
Excellent & $\geq 90$ &
\end{tabular}

From the students' scores, the lecturer can draw some reflection, that resuming activities is the most boring activities for the students. It can be seen from the result of students scores. It shows the average of students' scores are between Good and Very Good level. They tend to copy paste the work of other friends then give a little edit.
Assessment Rubric for Selecting Book For the first assignment, the students were selecting one book to read during he semester to accomplish the project of book summary and review to be reported every week. The book selected by the students individually. Here, the lecturer used the rubric below:

Table 2 Assessment Rubric for Selecting Book

\begin{tabular}{lcl}
\hline \multicolumn{1}{c}{ Grade } & Score & \multicolumn{1}{c}{ Indicator of activities } \\
\hline Fail & $\leq 40$ & $\begin{array}{l}\text { The contents are not accurate or too general. Reader do } \\
\text { not studying whatever or sometimes containing } \\
\text { misleading information. }\end{array}$ \\
Fair & $41-60$ & $\begin{array}{l}\text { The content is lacking accurate, because it does not } \\
\text { there is data factual, no add understanding reader. }\end{array}$ \\
Good & $61-80$ & $\begin{array}{l}\text { The content in general is accurate, but incomplete. } \\
\text { Readers can learn some facts implied, but they don't } \\
\text { add up new insights about the topic. }\end{array}$ \\
Very good & $81-90$ & $\begin{array}{l}\text { The content is accurate and complete. Readers add } \\
\text { insight about new the topics. } \\
\text { The content capable evocative reader for developing } \\
\text { thoughts, opening insights and motivating the readers. }\end{array}$ \\
\hline
\end{tabular}

From the students' scores, the lecturer can say that choosing book to be reviewed is the second most boring activities for the students. It can be seen from the result of students scores. It shows the average of students' scores are between Good and Very Good level. They tend to choose a simple book to read rather than more difficult book.

\section{Assessment Rubric for Short Video}

The third assignment, students were asked to make short review in the form of video. The assignments is individual project, so the grade is for each student individually. The lecturer evaluating and grading the assignments by viewing the students works that had been uploaded on YouTube and 
Instagram TV. Here, the lecturer used the rubric below:

Table 3 Assessment Rubric for Short Video

\begin{tabular}{lll}
\hline \multicolumn{1}{c}{ Grade } & Score & \multicolumn{1}{c}{ Indicator of activities } \\
\hline Fail & $\leq 40$ & $\begin{array}{l}\text { The speaker is anxious and uncomfortable, and read } \\
\text { various notes of the speak. Frequently, listener or } \\
\text { audiences are ignored. No eyes contact occurs because } \\
\text { the speaker is over look at screen. } \\
\text { Take a stand on the note, no ideas that developed } \\
\text { beyond note, monotonous voice }\end{array}$ \\
Fair & $41-60$ & $\begin{array}{l}\text { Generally speaker quiet, however with a tone which is } \\
\text { flat and often enough depends on note. Sometimes eye } \\
\text { contact with audineces are ignored. }\end{array}$ \\
Very good $\quad 81-90$ & $\begin{array}{l}\text { Speaker calm and use the right intonation, speak } \\
\text { without depending on the note, and interact intensively } \\
\text { with the listeners or audiences. Speaker always make } \\
\text { eye contact with the audiences. } \\
\text { Talking with spirit, transmit spirit and enthusiasm on } \\
\text { listener. Full of innovation and creativity in the video } \\
\text { had been made. }\end{array}$ \\
\hline
\end{tabular}

From the students' scores, the lecturer can conclude that making short videos is challenging activities, but more pleasure for the students. It can be seen from the result of students scores. It shows the average of students' scores are between Very Good and Excellent level. They tend are discussing with their frineds, they ask to the lecturer, how to solve some of problems related to making their video projects. Finally, they can accomplish the project well.

\section{Assessment Rubric for Giving Comments, Response and Criticism}

For the fourth assignment, the students were asked to give comments, responses and criticism to other works. The assignment is also individual duty. Each of them will be assesed by the following criteria.

Table 4 Assessment Rubric for Giving comments, response and criticism

\begin{tabular}{lcl}
\hline \multicolumn{1}{c}{ Grade } & Score & \multicolumn{1}{c}{ Indicator of activities } \\
\hline Fail & $\leq 40$ & $\begin{array}{l}\text { The contents are not accurate or too general. Reader do } \\
\text { not studying whatever or sometimes containing } \\
\text { misleading information. }\end{array}$ \\
Fair & $41-60$ & $\begin{array}{l}\text { The content is lacking accurate, because it does not } \\
\text { there is data factual, no add understanding reader. } \\
\text { The content in general is accurate, but incomplete. } \\
\text { Readers can learn some facts implied, but they don't } \\
\text { add up new insights about the topic. } \\
\text { The content is accurate and complete. Readers add } \\
\text { insight about new the topics. } \\
\text { The content capable evocative reader for developing } \\
\text { thoughts, opening insights and motivating the readers. }\end{array}$ \\
Excellent & $61-80$ &
\end{tabular}


From the students' scores, the lecturer can say that criticizing and giving comments to other friends' work is the most enjoyful and attractive activities for the students. It can be seen from the result of students scores. It shows the average of students' scores reach Excellent level. They visit and watch friends' videos, ask and give comments as well as become netizen in the virtual world.

\section{Assessment Rubric for Portofolio}

For the fifth assignment, the students were graded by their portofolio. The protofolio was graded individual individually. Here, the lecturer used the rubric below:

Table 5 Assessment Rubric for Portofolio of Participation

\begin{tabular}{|c|c|c|}
\hline Grade & Score & Indicator of activities \\
\hline Fail & $\leq 40$ & $\begin{array}{l}\text { The attendance in class is under } 50 \% \text { and no } \\
\text { submission of any assignments }\end{array}$ \\
\hline Fair & $41-60$ & $\begin{array}{l}\text { The attendance in class is under } 60 \% \text { but submit some } \\
\text { assignments }\end{array}$ \\
\hline Good & $61-80$ & $\begin{array}{l}\text { The attendance in class is }>60 \% \text {, submit all } \\
\text { assignments }\end{array}$ \\
\hline Very good & $81-90$ & $\begin{array}{l}\text { The attendance in class is }>70 \% \text {, submit all } \\
\text { assignments }\end{array}$ \\
\hline Excellent & $\geq 90$ & $\begin{array}{l}\text { The attendance in class is }>80 \% \text {, submit all } \\
\text { assignments }\end{array}$ \\
\hline
\end{tabular}

From the students' scores, the lecturer resume all of students activities which were archieved in Google Classroom. It shows the average of students' scores are between Good, Very Good, and Excellent level. After completing the Extensive Reading subject, the students have some competence, such as: using Google Classroom, Google Meet, Zoom, Youtube and Instagram TV as the media for teaching and learning online.

\section{CONCLUSION}

Pandemic Covid-19 disrupted the educational activities. Lecturer and students must adapt to the situation. After doing this research, it can be concluded such of the following: 1) online learning need some creativities both for lecturer and students in every aspects of teaching and learning processes; 2) the easiest and more accessible media used for online learning, especially on Extensive Reading in this case, is Google Classroom; 3) lecturer and students can improve their creative thinking when they are interact in distance learning.

\section{ACKNOWLEDGEMENT}

The researchers say special thanks for DEP. RISBANG KEMENRISTEK-BRIN- LLDIKTI VII who gives some funding for doing this research. The researchers also say thanks to LPPM UNHASY, Rector of Hasyim Asy'ari University, and Dean of Education Faculty, who always support the researchers in doing and finishing this research.

\section{REFERENCES}

Almarzooq, Z. I., Lopes, M., \& Kochar, A. (2020). Virtual Learning During the COVID-19 Pandemic: A Disruptive Technology in Graduate Medical Education. Journal of the 
American College of Cardiology, 75(20), 2635-2638. https://doi.org/10.1016/j.jacc.2020. 04.015

Arends, R. I. (2008). Learning toTeach : Belajar untuk Mengajar (7th ed.). Pustaka Pelajar.

Erdoğan, V. (2019). Integrating 4C Skills of 21st Century into 4 Language Skills in EFL Classes. International Journal of Education and Research, 7(11), 113-124. www.ijern.com

Fisher, R. (2004). What is Creativity? In R. F. \& M. William (Ed.), Unlocking Creativity: Teaching Across the Curriculum. David Fulton Publisher.

Mahmud, R. (2013). Evaluasi Penilaian 2: Unjuk Kerja. Artikel Pendidikan.

http://rifahmahmud.staff.stainsalati ga.ac.id/2013/01/29/evaluasi-danpenilaian-2-unjuk-kerja/

Misdi. (2018). Beyond Critical Thinking In Academic Writing: A Discourse Perspective. Jurnal Basis, 1(2), 51-56. http://ejournal.upbatam.ac.id/index .php/basis/article/view/306

Nitko, A. J. (1996). Educational Assessment of Student. PrenticeHall.

Pentury, H. J. (2017). Pengembangan Kreativitas Guru Dalam Pembelajaran Kreatif Pelajaran Bahasa Inggris. Faktor Jurnal Ilmiah Kependidikan, 4(3), 265272.

Suparno. (2001). Pembelajaran Bahasa Indonesia dengan Pendekatan Kontekstual.

Suryosubroto. (1996). Proses Belajar Mengajar di Sekolah. Rineka Cipta.

Widodo, S., \& Wardani, R. K. (2020). Mengajarkan Keterampilan Abad $214 \mathrm{C}$ (Communication,
Collaboration, Critical Thinking And Problem Solving, Creativity And Innovation) Di Sekolah Dasar. MODELING: Jurnal Program Studi PGMI, 7(2), 185-197. https://www.researchgate.net/publi cation $/ 348742516$

Wijaya, Cece dan Rusyan, T. (1991). Kemampuan Dasar Guru Dalam Proses Belajar Mengajar. Rosda Karya. 
